\title{
Preservice Agriculture Teachers' Perceived Self-Efficacy of Specific SAE Competencies
}

\author{
E. Rubenstein ${ }^{1}$, J. Scott ${ }^{2}$
}

\begin{abstract}
With the implementation of the supervised agricultural experience (SAE) within school-based agricultural education (SBAE), hands-on learning has changed how students learn in the classroom. SAE programs, a key component of agricultural education, are an example of experiential learning within the SBAE model. The implementation of SAE experiences has been often viewed as difficult for many teachers, and many new agricultural educators struggle with implementing SAE into their classroom instruction. Therefore, this study sought to determine the self-efficacy of preservice agriculture teachers towards the American Association for Agricultural Education-Supervised Agricultural Experience (AAAE) SAE competencies. Results indicated that a majority of preservice teachers considered SAE an important aspect of the SBAE model. However, results indicated that few competencies showed significant differences between pre- and post-completion of the agricultural program, and only two competencies showed significance by gender. Data indicates that teacher preparation programs have been successful in preparing students to develop, implement, and supervise SAE programs during student teaching. The researchers recommend that further research should examine additional agricultural teacher preparation programs and determine the self-efficacy of cooperating teachers in the classroom.
\end{abstract}

\section{Keywords}

Supervised agricultural experience, agricultural education, social cognitive theory, experiential learning

1. Eric Rubenstein, Associate Professor, College of Agricultural \& Environmental Science, University of Georgia, 0133 Four Towers, 405 Station Rd, Athens, GA 30602, erubenstein@uga.edu, (D) https://orcid.org/0000-0002-8799-2502

2. James Scott, Graduate Research Assistant, University of Georgia, 129A Four Towers Building, 405 Station Rd, Athens, GA 30602, jamesd.scott@uga.edu, (iD) https://orcid.org/0000-0003-4807-4378 


\section{Introduction and Problem Statement}

With the conception of the home project by Rufus Stimson in the early twentieth century, the school-based agricultural education (SBAE) model has been forever changed by creating a unique programmatic offering in Agricultural Education (Phipps et al., 2008). Since then, the project method has changed and adapted to meet the needs of all students (Phipps et al., 2008). Experiential learning has been best summarized through learning by doing and encouraging students to reflect on their experience (Morris, 2020; Phipps \& Osborne, 1988; Phipps et al., 2008; Roberts, 2006). Teachers should be prepared to make the experiences educational for the student and should be prepared to assist in planning and executing each student's SAE.

Preservice agriculture teacher programs may not fully prepare preservice teachers for teaching SAE in the classroom, and the self-efficacy of preservice teachers has often been unknown (McLean \& Camp, 2000; Rubenstein et al., 2014; Stair \& Warner, 2012; Talbert et al., 2014). Additionally, the self-efficacy of these preservice teachers has often been unknown.

Furthermore, McLean and Camp (2000) indicated that three of 10 preservice teacher education programs, included in the study, actually taught a course focused on SAE to preservice teachers. These preservice agricultural programs spend a less significant amount of time teaching SAE as opposed to instruction related to the National FFA Organization (McLean \& Camp, 2000). Rubenstein et al. (2014), concluded that a majority of preservice teachers perceived SAE as important or somewhat important, however preservice teachers indicated low self-efficacy towards several competencies. Therefore, this research study aimed to further previous research and examine preservice teachers' self-efficacy towards the specific American Association for Agricultural Education (AAAE) SAE competencies before and after completing an agriculture teacher preparation program.

\section{Theoretical and Conceptual Framework}

This study was guided by Bandura's (1986) Social Cognitive Theory and Schunk's (2012) research on the role gender plays in self-efficacy. Bandura (1986) stated that learning is achieved through interactions between the learner, environment, and behaviors. These interactions are bidirectional, built into a triad, where the factors do not have to occur in the same moment. Social cognitive theory focuses on the learner with personal factors influencing learning. Within personal factors, self-efficacy plays a major role (Bandura, 1986). As mentioned, teachers are responsible for many aspects of SAEs. This includes assisting in developing, implementing, and executing plans set forth, to aid in the success of the student. For a teacher to perform and assist the student, personal factors such as self-efficacy, guide them throughout all aspects of SAEs. Therefore, this study focused on preservice teachers' selfefficacy and perceptions of SAE regarding their ability to perform a given list of competencies.

Bandura (1986) defines self-efficacy as the judgments of the capabilities people have to organize and execute action needed to attain a specific performance. It is a belief about what one is capable of doing as opposed to knowing what to do (Schunk, 2012). Schunk also states 
that to gauge self-efficacy, individuals assess their skills and capabilities and how those skills form actions. Actual experiences and performances then offer the most information for assessing one's self-efficacy (Schunk, 2012).

Self-efficacy plays a key role in this study in the performance of preservice agricultural educators, but Schunk (2012) also stated that gender differences often relate to differences in self-efficacy among vocational career choices. However, a lack of research exists in determining the correlations between gender and self-efficacy. Additionally, within the performance of preservice teachers, achievement also plays a key role in self-efficacy. Those who view themselves as having low-self efficacy will often avoid attempting tasks and may also doubt their learning capabilities as opposed to those who are efficacious (Schunk, 2012). Not only does teacher self-efficacy have an impact on instructional methods and planning, but it also has an impact on student learning (Schunk, 2012). Acknowledging these factors, it is believed one's self-efficacy may in turn influence the progress and achievement of students and teachers (Schunk, 2012).

In addition to limited research and little data in determining where SAE instruction should focus concerning SAE course work, it is unclear how preservice agriculture teachers view their perceived self-efficacy towards SAE. Therefore, the assumption can be made that those with limited interaction with SAE and SBAE will be less efficacious towards the specific AAAE-SAE competencies as opposed to those with the experience.

\section{Purpose}

The purpose of this study was to examine the self-efficacy of preservice teachers' ability to perform the SAE Competencies developed through the American Association for Agricultural Education (American Association for Agricultural Education, 2013). The specific objectives that guided this study were:

1. To determine the influence of prior SAE experience and beliefs on preservice agriculture teachers' SAE self-efficacy.

2. Examine the influence of core agricultural education certification courses on preservice agriculture teachers' SAE self-efficacy.

3. Examine the differences in SAE self-efficacy among genders of preservice agriculture teachers.

\section{Methods}

To determine the preservice teachers' perceived abilities to conduct SAE in their SBAE programs, a paper-based pre-survey was administered to senior agricultural education students before the completion of the core agricultural education certification courses, where all SAE content is taught. The pre-survey was followed by a post-survey which was administered upon completion of their 15-week student teaching experience the following spring semester. The span between the administration of the two instruments was nine months. The survey was administered to 15 preservice teachers who completed the agricultural education certification 
program at The University of Georgia using a questionnaire that was developed by Rubenstein et al (2014). The survey was developed based on the core competencies approved by AAAE. The instrument was found to be reliable by Rubenstein et al. (2014) with a post-hoc reliability found to be .95. The instrument was used unchanged from the previous study. The questionnaire consisted of 20 Likert-type items that measured preservice teachers' self-efficacy of each AAAESAE Competency. The instrument utilized a 5-point Likert-type scale that ranged from (5) high, (4) moderately high, (3) neutral, (2) moderately low, and (1) low. Data were analyzed using descriptive statistics and the pre-post responses were analyzed using a dependent samples $t$ test to determine the change in the preservice teachers' perceived ability to perform the SAE competencies. This study was utilized as a snapshot to understand the influence of the program, with a limited population and small sample size.

The sample of this study consisted of graduating preservice agriculture teachers from one agricultural education preparation program at a The University of Georgia $(n=15)$. All participants were seniors in their final year of certification courses and student teaching. A census was utilized in this study.

Data were collected using a paper-based questionnaire previously designed by Rubenstein et al. (2014). The questionnaire was administered in a face-to-face format (Dillman et al., 2009). Prior to utilization, the original survey instrument developed by Rubenstein et al (2014) was reviewed by a panel of experts who examined the document for content validity within the individual program, and then deemed acceptable in its current form for this study, as the population in both studies were preservice teachers.

Responses were analyzed using descriptive statistics to determine the perceived self-efficacy of preservice agriculture teachers in completing individual SAE competencies. Independent samples $t$-tests were used to determine the ability of preservice teachers prior/post completion of certification courses and student teaching, as well as the differences between students who identify as male or female towards their performance of SAE competencies. Researchers utilized independent samples $t$-tests, as this method is often found to be robust to violations of the normal population assumption (Agresti \& Finlay, 2009). The alpha level of statistical significance was set $a$ priori at .05.

\section{Findings}

Participants ( $n=15$ ) not only responded on their ability to perform AAAE-SAE competencies, but demographic information was also collected (see Table 1). Approximately two-thirds of respondents $(60 \%, n=9)$ identified as female. A majority of respondents $(93 \%, n=14)$ selfreported they were Caucasian, Non-Hispanic. Additionally, the majority of participants were involved in high school agriculture education and previous SAE experience $(100 \%, n=15),(93 \%$, $n=14$ ) respectively. A majority responded they received instruction from at least one course focused on SAE, yet $13 \%$ indicated no previous instruction on SAE. Although 7 of 15 participants (47\%) believed that SAE was very important in coursework before completing the program, post-survey results indicated that 14 participants perceived SAE as very important. 


\section{Table 1}

Demographics of Preservice Teachers $(n=15)$

\begin{tabular}{|c|c|c|}
\hline Characteristic & $n$ & $\%$ \\
\hline \multicolumn{3}{|l|}{ Gender } \\
\hline Female & 9 & 60 \\
\hline Male & 6 & 40 \\
\hline \multicolumn{3}{|l|}{ Ethnicity } \\
\hline Hispanic & 1 & 7 \\
\hline Caucasian, Non-Hispanic & 14 & 93 \\
\hline \multicolumn{3}{|l|}{ High School Agriculture Education } \\
\hline Yes & 15 & 100 \\
\hline No & 0 & 0 \\
\hline \multicolumn{3}{|l|}{ SAE Experience } \\
\hline No Previous Experience & 1 & 7 \\
\hline High School Experience & 14 & 93 \\
\hline \multicolumn{3}{|c|}{ Coursework Regarding SAE During Teacher Preparation Program } \\
\hline Entire Course on SAE & 1 & 7 \\
\hline A Portion of 1 Course & 6 & 40 \\
\hline A Portion of More Than 1 Course & 6 & 40 \\
\hline No Instruction Provided & 2 & 13 \\
\hline \multicolumn{3}{|l|}{ Importance of SAE in SBAE } \\
\hline Not Important & 0 & 0 \\
\hline Somewhat Important & 1 & 7 \\
\hline Neither Important or Not Important & 0 & 0 \\
\hline Somewhat Important & 7 & 47 \\
\hline Very Important & 7 & 47 \\
\hline \multicolumn{3}{|l|}{ Certification Status } \\
\hline Through a Teacher Preparation Program & 14 & 93 \\
\hline Through Alternative Certification Routes & 1 & 7 \\
\hline Provisionally Certified Currently & 0 & 0 \\
\hline
\end{tabular}

Note. SAE = supervised agricultural experience; SBAE = school-based agricultural education

Preservice teachers' self-efficacy towards SAE and SBAE increased between the pre-survey to post-survey on 16 items, and Table 2 illustrated that two competencies were statistically significant $(p<.05)$. Preservice teachers reported that their ability to provide individualized instruction related to a student's SAE increased from 3.40 to $3.87(p=.04)$. However, their ability to motivate students to complete an SAE program decreased from 4.40 to $3.67(p=.00)$ after completion of the program. 


\section{Table 2}

Preservice Teacher Self-Efficacy Towards AAAE-SAE Competencies ( $n=15)$

\begin{tabular}{|c|c|c|c|c|}
\hline Item: My ability to ... & Pre-M & Post-M & $p$ & $t$ \\
\hline Motivate students to complete an SAE program & 4.40 & 3.67 & .00 & 4.78 \\
\hline $\begin{array}{l}\text { Provide individualized instruction related to a student's SAE } \\
\text { program }\end{array}$ & 3.40 & 3.87 & .04 & -.217 \\
\hline Clearly communicate the purpose of SAE programs with others & 3.60 & 4.00 & .11 & -1.70 \\
\hline Instruct students in how to complete SAE programs & 3.53 & 3.80 & .16 & -1.47 \\
\hline $\begin{array}{l}\text { Assist students in selecting SAE programs that meet their } \\
\text { individual abilities }\end{array}$ & 3.47 & 3.80 & .17 & -1.44 \\
\hline Inform administrators about the benefits of SAE programs & 4.07 & 4.27 & .33 & -1.00 \\
\hline Evaluate SAE programs & 3.73 & 3.93 & .33 & -1.00 \\
\hline Identify SAE programs that connect to agriculture curriculum & 3.93 & 4.13 & .38 & -.90 \\
\hline $\begin{array}{l}\text { Encourage students to complete a diary record for their SAE } \\
\text { program }\end{array}$ & 3.80 & 4.00 & .42 & -.82 \\
\hline $\begin{array}{l}\text { Assist students in completing a record of the financial } \\
\text { transactions related to their SAE program }\end{array}$ & 3.47 & 3.73 & .43 & -.81 \\
\hline $\begin{array}{l}\text { Assist students in developing SAE programs that meet their } \\
\text { aptitude }\end{array}$ & 3.33 & 3.53 & .45 & -.76 \\
\hline $\begin{array}{l}\text { Assist students in planning an appropriate SAE program that } \\
\text { meets their needs }\end{array}$ & 3.47 & 3.67 & .45 & -.76 \\
\hline Build positive relationships with administrators & 4.20 & 4.33 & .49 & -.70 \\
\hline $\begin{array}{l}\text { Evaluate student's competency development within their SAE } \\
\text { program }\end{array}$ & 3.20 & 3.33 & .49 & -.69 \\
\hline Identify SAE programs within a community & 3.67 & 3.80 & .54 & -.62 \\
\hline $\begin{array}{l}\text { Clearly communicate the procedures of SAE programs with } \\
\text { others }\end{array}$ & 3.53 & 3.67 & .54 & -.62 \\
\hline Enhance student learning using SAE as a motivation tool & 3.67 & 3.53 & .58 & .56 \\
\hline $\begin{array}{l}\text { Coordinate communications between a student, parent, } \\
\text { employer, and myself }\end{array}$ & 4.07 & 3.93 & .61 & .52 \\
\hline $\begin{array}{l}\text { Provide students meaningful supervision during their SAE } \\
\text { program }\end{array}$ & 4.07 & 3.93 & .63 & .49 \\
\hline $\begin{array}{l}\text { Provide sufficient notice to those involved in a supervisory visit } \\
\text { of the date and time }\end{array}$ & 4.27 & 4.13 & .65 & .46 \\
\hline Identify SAE programs that are beneficial for individual students & 3.73 & 3.80 & .77 & -.29 \\
\hline $\begin{array}{l}\text { Assist students in acquiring necessary resources to complete an } \\
\text { SAE program }\end{array}$ & 3.60 & 3.53 & .81 & .24 \\
\hline Encourage students to improve their SAE programs & 4.20 & 4.20 & 1.00 & .00 \\
\hline Use SAE programs as a tool for increasing student learning & 4.00 & 4.00 & 1.00 & .00 \\
\hline $\begin{array}{l}\text { Increase community involvement in agriculture education using } \\
\text { SAE programs }\end{array}$ & 3.73 & 3.73 & 1.00 & .00 \\
\hline
\end{tabular}

Note. 5 = high; 4 = moderately high; 3 = neutral; 2 = moderately low; 1 = low 
As noted in Table 3, only two competencies showed significance by gender. Table 3 also illustrates that if one gender perceived their self-efficacy toward a competency highly, the opposite would show lower self-efficacy. Of the two competencies with significance, both males and females indicated a large decrease in ability towards providing individualized instruction related to a student's SAE program. However, it can be noted that females showed a larger change from the pre-survey to the post-survey $(M=-.67)$, while males indicated a lesser decrease $(M=-.17)$. Furthermore, Table 3 indicates that male preservice agriculture teachers perceive their ability to evaluate student's competency development within their program as higher upon completion of the preparation program $(M=.17)$ while females perceive their ability as weaker upon completion $(M=-.33)$. Thus, statistical significance can be noted of this competency $(p=.02)$. 


\section{Table 3}

Preservice Teacher Self-Efficacy Towards AAAE-SAE Competencies Based on Gender

\begin{tabular}{|c|c|c|c|c|c|}
\hline \multirow[b]{2}{*}{ Item: My ability to ... } & \multicolumn{2}{|c|}{ Male $(n=6)$} & \multicolumn{2}{|c|}{ Female $(n=9)$} & \multirow[b]{2}{*}{$p$} \\
\hline & $M$ & $S D$ & $M$ & $S D$ & \\
\hline $\begin{array}{l}\text { Evaluate student's competency development within their } \\
\text { SAE program }\end{array}$ & .17 & .40 & -.33 & .86 & .02 \\
\hline $\begin{array}{l}\text { Provide individualized instruction related to a student's SAE } \\
\text { program }\end{array}$ & -.17 & .40 & -.67 & 1.00 & .03 \\
\hline Enhance student learning using SAE as a motivation tool & .00 & .63 & .22 & 1.09 & .05 \\
\hline $\begin{array}{l}\text { Assist students in developing SAE programs that meet their } \\
\text { aptitude }\end{array}$ & .00 & .63 & -.33 & 1.22 & .07 \\
\hline $\begin{array}{l}\text { Assist students in selecting SAE programs that meet their } \\
\text { individual abilities }\end{array}$ & .00 & .63 & -.56 & 1.01 & .10 \\
\hline $\begin{array}{l}\text { Clearly communicate the purpose of SAE programs with } \\
\text { others }\end{array}$ & -.17 & .75 & -.56 & 1.01 & .27 \\
\hline $\begin{array}{l}\text { Clearly communicate the procedures of SAE programs with } \\
\text { others }\end{array}$ & .00 & .63 & -.22 & .97 & .27 \\
\hline $\begin{array}{l}\text { Assist students in completing a record of financial } \\
\text { transactions in their SAE program }\end{array}$ & .50 & 1.04 & -.78 & 1.20 & .27 \\
\hline $\begin{array}{l}\text { Encourage students to complete a diary record for their SAE } \\
\text { program }\end{array}$ & -.33 & .51 & -.11 & 1.16 & .28 \\
\hline Motivate students to complete an SAE program & 1.00 & .63 & .56 & .52 & .36 \\
\hline $\begin{array}{l}\text { Assist students in acquiring necessary resources to complete } \\
\text { an SAE program }\end{array}$ & .50 & 1.22 & -.22 & .97 & .39 \\
\hline Encourage students to improve their SAE programs & -.17 & .75 & .11 & 1.16 & .42 \\
\hline $\begin{array}{l}\text { Identify SAE programs that are beneficial for individual } \\
\text { students }\end{array}$ & .33 & 1.03 & -.33 & .70 & .44 \\
\hline $\begin{array}{l}\text { Identify SAE programs that connect to agriculture } \\
\text { curriculum }\end{array}$ & .17 & .75 & -.44 & .88 & .50 \\
\hline Use SAE programs as a tool for increasing student learning & .00 & .89 & .00 & .86 & .53 \\
\hline Evaluate SAE programs & -.17 & .75 & -.22 & .83 & .54 \\
\hline $\begin{array}{l}\text { Assist students in planning an appropriate SAE program that } \\
\text { meets their needs }\end{array}$ & .33 & .81 & -.56 & 1.01 & .56 \\
\hline $\begin{array}{l}\text { Increase community involvement in agriculture education } \\
\text { using SAE programs }\end{array}$ & .33 & 1.03 & -.22 & 1.39 & .57 \\
\hline $\begin{array}{l}\text { Provide students meaningful supervision during their SAE } \\
\text { program }\end{array}$ & .50 & .83 & -.11 & 1.16 & .67 \\
\hline Instruct students in how to complete SAE programs & .17 & .75 & -.56 & .52 & .68 \\
\hline $\begin{array}{l}\text { Coordinate communications between a student, parent, } \\
\text { employer, and myself }\end{array}$ & .00 & 1.09 & .22 & .97 & .83 \\
\hline $\begin{array}{l}\text { Provide sufficient notice to those involved in a supervisory } \\
\text { visit of the date and time }\end{array}$ & .17 & 1.16 & .11 & 1.16 & .85 \\
\hline Build positive relationships with administrators & -.17 & .75 & -.11 & .78 & .88 \\
\hline Inform administrators about the benefits of SAE programs & -.17 & .75 & -.22 & .83 & .96 \\
\hline Identify SAE programs within a community & -.33 & .81 & .00 & .86 & 1.00 \\
\hline
\end{tabular}

Note. 5 = high, 4 = moderately high, $3=$ neutral, $2=$ moderately low, $1=$ low 


\section{Conclusions, Discussion, and Recommendations}

Based on the findings of this study, several conclusions can be drawn. However, the authors noted limitations, which included a small sample size and its effect on generalization of the results. Not only is SAE perceived to be of greater importance upon completion of the program but preservice teachers' self-efficacy increased among 16 competencies. Only two competencies were noted with statistical significance among preservice teachers $(p<.05)$, with a significant decrease noted for one item; motivating students to complete an SAE program. Previous studies have indicated that teachers struggle with SAEs, and many teachers fail to implement programs completely (Dyer \& Osborne, 1995; Robinson \& Haynes, 2011; Rubenstein et al., 2014). As noted in Dyer \& Osborne (1995), when teachers indicate low self-efficacy towards SAEs and struggle with implementation, there is difficulty motivating students leading to decreased participation.

While there is limited research that seeks to identify the differences in self-efficacy and gender in agricultural educators, researchers determined that there was little indication gender impacted self-efficacy of specific SAE competencies. Prior research indicated a large difference in male teachers compared to female teachers, yet did not identify key differences in perceptions of self-efficacy (Edwards \& Briers, 2001; Young \& Edwards, 2005). Recent research indicates a large gap between female and male agricultural educators, and Rubenstein et al. (2014) indicated nearly three-quarters of respondents as female. However, respondents who identified as male reported a higher increase in self-efficacy in 17 competencies, but also reported a greater decrease than females in five competencies; identify SAE programs within a community, encourage students to complete a diary record for their SAE program, evaluate SAE programs, encourage students to improve their SAE programs, and build positive relationships with administrators. Further examination indicated that both female and male respondents reported lower self-efficacy of providing individualized instruction related to a student's SAE program.

While previous research did not indicate significant changes, anecdotal evidence from pre- and post-survey means illustrated an increase in each competency except the eight which decreased. However, researchers concluded there was little to no difference in self-efficacy of participants prior to and after completion of a teacher preparation course. These results indicate that agricultural teacher preparation programs are successful to an extent in preparing teachers to implement SAE into the classroom. Nonetheless, previous research indicates that agriculture teachers struggle with the implementation of these programs in the classroom (Talbert et al., 2014). Therefore, researchers express the importance of investigating the impacts of agricultural teacher programs, as previous research also indicates that agriculture teachers pose the greatest impact on SBAE and SAEs (Dyer \& Osborne, 1995; Phipps et al., 2008; Rubenstein et al., 2014).

Additionally, determining where gaps occur between teacher preparation programs and practicing teachers should be examined more thoroughly. Previous research indicates that preservice agricultural teacher programs may not fully prepare students for teaching SAE in the 
classroom (Rubenstein et al., 2014). Rubenstein et al. (2014) concluded that while programs would seem to be preparing teachers, teachers struggle with implementation in the classroom, leading to the suggestion that a gap exists between what is taught and what is practiced. Furthermore, within this study, researchers agreed there were indications student teaching impacted the self-efficacy of preservice teachers, and identified several competencies with components of classroom interaction that either increased or decreased. As previously mentioned, teachers in the classroom struggle with the implementation of SAE (; Dyer \& Osborne, 1995; Rubenstein et al., 2014; Talbert et al., 2014), which impacts student teachers.

\section{Recommendations}

Based on the results of the study, several recommendations have been developed for future research. These include examining the level and depth of SAE instruction in agricultural teacher preparation programs across the United States, how agriculture teacher preparation programs are preparing preservice teachers to develop individual student SAE programs, cooperating teachers' self-efficacy towards the AAAE-SAE competencies, and agricultural educators who are new to teaching and those who have been teaching for many years to determine the differences in self-efficacy towards specific competencies among teacher experience and performance.

Furthermore, the researchers propose recommendations for agricultural teacher educators which include developing SAE implementation guides to support new teachers in motivating students to complete SAEs, and provide additional training opportunities for preservice and inservice agriculture teachers to learn about SAE development, implementation, and supervision.

\section{References}

Agresti, A., \& Finlay, B. (2009). Statistical methods for the social sciences (4th ed.). Prentice-Hall.

American Association for Agricultural Education. (2013). Teacher education SAE competencies. http://aaaeonline.org/Resources/Documents/SIG\%20Files/SAE\%20Competencies.pdf

Bandura, A. (1986). Social foundations of thought and action: A social cognitive theory. Prentice-Hall.

Dillman, D. A., Smyth, J. D., \& Christian, L. M. (2009). Internet, mail, and mixed-mode surveys; The tailored design method (3rd ed.). Wiley.

Dyer, J. E., \& Osborne, E. W. (1995). Participation in supervised agricultural experience programs: A synthesis of research. Journal of Agricultural Education, 36(1), 6-14. https://doi.org/10.5032/jae.1995.01006

McLean, R. C., \& Camp, W. G. (2000). An examination of selected preservice agricultural teacher education programs in the United States. Journal of Agricultural Education, 41(2), 2535. https://doi.org/10.5032/jae.2000.02025 
Morris, T. H. (2020). Experiential learning - a systematic review and revision of Kolb's model. Interactive Learning Environments, 28(8), 1064-1077. https://doi.org/10.1080/10494820.2019.1570279

Phipps, L. J., \& Osborne, E. W. (1988). Handbook on agricultural education in public schools (5th ed.). Interstate.

Phipps, L. J., Osborne, E. W., Dyer, J. E., \& Ball, A. (2008). Handbook on agricultural education in public schools (6th ed.). Thomson Delmar.

Roberts, T. G. (2006). A philosophical examination of experiential learning theory for agricultural educators. Journal of Agricultural Education, 47(1), 17-29. https://doi.org/10.5032/jae.2006.01017

Robinson, J. S., \& Haynes, J. C. (2011). Value and expectations of supervised agriculture experiences as expressed by agriculture instructors in Oklahoma who were alternatively certified. Journal of Agricultural Education, 52(2), 47-57. https://doi.org/10.5032/jae.2011.02047

Rubenstein, E. D., Thoron, A. C., \& Estepp, C. M. (2014). Perceived self-efficacy of preservice agriculture teachers toward specific SAE competencies. Journal of Agricultural Education, 55(4), 72-84. https://doi.org/10.5032/jae.2014.04072

Schunk, D. H. (2012). Learning theories: An educational perspective (6th ed.). Pearson.

Schunk, D. H. (2020). Learning theories: An educational perspective (8th ed.). Pearson.

Stair, K. S., \& Warner, W. J. (2012). Identifying concerns of preservice and in-service teachers in agricultural education. Journal of Agricultural Education, 53(2), 153-164. https://doi.org/10.5032/jae.2012.02153

Stimson, R. W. (1919). Vocational agricultural education by home projects. Macmillan.

Talbert, B. A., Vaughn, R., Croom, B., \& Lee, J. S. (2014). Foundations of agricultural education (3rd ed.). Pearson.

Young, R. B., \& Edwards, M. C. (2005). A profile of cooperating teachers and centers in Oklahoma: Implications for the student teaching experience in agricultural education. Journal of Southern Agricultural Education Research, 55(1), 60-73. http://www.jsaer.org/pdf/Vol55/55-01-060.pdf

(C) 2021 by authors. This article is an open access article distributed under the terms and conditions of the Creative Commons Attribution license (http://creativecommons.org/licenses/by/4.0/). 